Original Research

\title{
Characteristics of Soil Heavy Metal Contents and Its Source Analysis in Affected Areas of Luning Coal Mine in Huaibei Coalfield
}

\author{
Yaru Zhang ${ }^{1}$, Herong Gui ${ }^{1 *}$, Yiheng Huang ${ }^{1}$, Hao Yu ${ }^{1,2}$, Jun Li ${ }^{1,3}$, \\ Meichen Wang ${ }^{1,2}$, Hongxia Fang ${ }^{1,2}$, Yaqi Jiang ${ }^{1,2}$, Chunlei Wang ${ }^{1,2}$, Chen Chen ${ }^{1,2}$ \\ ${ }^{1}$ National Engineering Research Center of Coal Mine Water Hazard Controlling, Suzhou University, \\ Suzhou, Anhui, China \\ ${ }^{2}$ School of Earth and Environment, Anhui University of Science and Technology, Huainan, Anhui, China \\ ${ }^{3}$ School of Resources and Environmental Engineering, Hefei University of Technology, Hefei, Anhui, China
}

Received: 26 May 2020

Accepted: 17 July 2020

\begin{abstract}
This study analyzed the content characteristics, ecological risks, vertical migration characteristics and sources of soil heavy metals $(\mathrm{Cr}, \mathrm{Ni}, \mathrm{Cu}, \mathrm{Zn}, \mathrm{As}, \mathrm{Cd}$ and $\mathrm{Pb}$ ) in affected areas of Luning Coal Mine. Results showed that the average contents of $\mathrm{Cr}, \mathrm{Pb}, \mathrm{Cu}$, As and $\mathrm{Cd}$ exceeded the surface soil background values of Anhui Province, but the risk of soil ecological environment was low. Cd had the largest single factor pollution index, As followed, and $\mathrm{Cd}$ in 14 sampling points reached the warning limit, $95 \%$ of the samples were in moderate hazard, $5 \%$ of the samples were in strong hazard, but the potential ecological hazard index of many kind of heavy metals was 81.81 121.41, which was low ecological hazard. The difficulty of vertical migration of heavy metals in soil was from easy to difficult: $\mathrm{Cr}>\mathrm{Ni} \& \mathrm{Cu}>\mathrm{As}>\mathrm{Zn}>\mathrm{Cd} \& \mathrm{~Pb} ; \mathrm{Cu}, \mathrm{Zn}$ and $\mathrm{Pb}$ were related to automobile exhaust emissions and transportation dust, $\mathrm{Cd}$ and $\mathrm{Ni}$ were mainly caused by natural geological processes, leaching of coal gangue hill and the discharge of industrial pollutants, As was mainly caused by agricultural activities, and $\mathrm{Cr}$ was closely related to coal combustion.
\end{abstract}

Keywords: soil heavy metals, content characteristics, vertical migration, potential ecological risk evaluation method, principle component analysis

\section{Introduction}

China is rich in coal resources and is the world's largest coal producer and consumer. However, with the development and utilization of coal resources, a large

*e-mail: guiherong@163.com number of wastes, such as coal gangue, mine water and fly ash, will be generated, causing pollution to the surrounding environment of the mining area [1-5]. In particular, under the action of spontaneous combustion, rainwater leaching and wind blowing, the trace heavy metal elements in the coal gangue and fly ash piled in the open air diffuse and migrate to the surrounding environment media, polluting the soil and leading to 
the increase of heavy metal contents in the soil [6-10]. Coal mine power plants will release toxic and harmful substances during coal combustion, especially heavy metal elements, will have a serious impact on the mining environment. Heavy metal pollution has the characteristics of concealment, lag and long-term. It is not easy to be biodegraded, but easy to be absorbed and accumulated by organisms, and finally harms human health through the food chain [11]. Soil is the most basic resource for all life on earth to survive and develop. Once polluted, it will be difficult to repair. Therefore, it is particularly important to analyze the ecological risk of soil heavy metal pollution in the areas affected by coal mining engineering.

In recent years, predecessors have made a lot of studies on the content characteristics, spatial distribution, migration rules, ecological risks and source analysis of heavy metals in the soil around coal mines by using various methods. For example, Xintian Yuan [12] et al. studied the pollution characteristics of heavy metals such as $\mathrm{Cu}, \mathrm{Zn}, \mathrm{Cr}, \mathrm{Cd}, \mathrm{Pb}, \mathrm{Hg}$ and $\mathrm{As}$ in the topsoil of farmland around the coal mine area in Suzhou. Results showed that the surface soil of the farmland within $500 \mathrm{~m}$ of the coal mine area except $\mathrm{Cu}$, $\mathrm{Zn}$ and $\mathrm{Pb}, \mathrm{Cr}, \mathrm{Cd}, \mathrm{Hg}$ and $\mathrm{As}$ exceeded the national soil environmental quality standards (Level I), where As, Cd were slightly polluted, $\mathrm{Cr}$ was moderately polluted, and $\mathrm{Hg}$ was heavily polluted. Jianmei Yuan [13] et al. measured the contents of heavy metals $\mathrm{Cr}, \mathrm{Ni}$, $\mathrm{Cu}, \mathrm{Zn}, \mathrm{Cd}, \mathrm{Pb}, \mathrm{As}$ and $\mathrm{Hg}$ in six coal mining areas in Chongqing. Results showed that except $\mathrm{Cr}, \mathrm{Ni}, \mathrm{Cu}$, $\mathrm{Zn}$ and $\mathrm{Cd}$ were exceeding the standard in some soil samples in the study area, all other soil samples met the national soil environmental quality standards, the comprehensive pollution level was clean, and the potential ecological risk was mild or moderate. Haimin $\mathrm{Su}$ [14] et al. studied the potential ecological harm of heavy metal pollution in the soil around the Suzhou mining area by using Hakanson potential ecological risk index method. They thought that except $\mathrm{Cd}$ and $\mathrm{Hg}$, the potential ecological risk coefficients of heavy metals were all mild risk hazards, $\mathrm{Cd}$ and $\mathrm{Hg}$ had a high contribution rate in the farmland ecological pollution of Suzhou mining area. Xiaodong Guo [15] et al. measured the contents of $\mathrm{As}, \mathrm{Hg}, \mathrm{Cu}, \mathrm{Pb}, \mathrm{Zn}, \mathrm{Cr}, \mathrm{Ni}$ and $\mathrm{Cd}$ in the farmland soils of Hunchun basin in order to understand the characteristics of heavy metal pollution. Results showed that the contents of $\mathrm{Pb}$ and $\mathrm{Zn}$ were lower than the background values of Jilin Province, and the contents of other heavy metals exceeded the background values, especially $\mathrm{Hg}$. More than $20 \%$ of the samples were obviously polluted by $\mathrm{Hg}$, while less than $10 \%$ of the other elements were polluted. Abdugheni Abliz [16] et al. studied the sources of heavy metals in soils of Northwest coal mining areas. $\mathrm{Zn}$ and $\mathrm{Cu}$ came from parent materials, $\mathrm{Cr}$, $\mathrm{As}$ and $\mathrm{Hg}$ came from human activities such as coal combustion, chemical industry and transportation, and $\mathrm{Pb}$ was influenced by both natural factors and human activities.
Coal mining history, development scale and the use of coal resources are different, the impact on the surrounding environment is completely different. This paper choice the Luning coal mine, which has the longest mining history, the largest development scale and has the pithead power plant in the Sunan mining area, to analyze the contents and migration of $\mathrm{Cr}, \mathrm{Ni}$, $\mathrm{Cu}, \mathrm{Zn}, \mathrm{As}, \mathrm{Cd}$ and $\mathrm{Pb}$ in the surrounding soil. On this basis, the evaluation of soil environmental quality and potential ecological risk in coal mine affected areas was carried out, and the possible sources of heavy metal pollution were discussed to provide a scientific basis for soil environmental protection and restoration management around the coal mine.

\section{Materials and Methods}

\section{Overview of the Study Area}

Huaibei coalfield is located in the southern part of Huanghuaihai plain and the northern part of Anhui Province. The territory is rich in coal resources, is an important coal energy base in east China. Luning coal mine is located in the Sunan mining of Huaibei coalfield, covering an area of $23 \mathrm{~km}^{2}$. It was completed and put into operation in December 1969, and had a mining history of more than 50 years. The mine produces 2.2 million tons of coal a year. In July 2015, the mine had a installed capacity of $30,000 \mathrm{kw}$ and an average daily power generation of 46,000 degrees. After years of coal mining and utilization, great changes had taken place in the surface environment of the mining area. In particular, coal gangue hill and collapsed lake constitute a potential threat to soil pollution around the mining area. Tuo river in the study area is a seasonal river. Terrain is flat, elevation in $+24 \mathrm{~m}$ or so. Sand ginger black soil is the main soil type in the region. The soil is deep, the organic matter content is not high, the soil clay content is high, the texture is viscous, the structure and the porosity are poor. The main crops are corn and wheat. Summer warm and rainy, the dominant wind direction is southeast wind. Winter cold and dry, the dominant wind direction is northeast wind. The geographical location of the study area was shown in Fig. 1a-b).

\section{Sample Collection and Processing}

In July 2019, based on the full understanding of the land use status and geological background of the study area, taking coal gangue hill and pithead power plant as the center, along the southeast downwind direction, the fan-shaped distribution method was used to collect 19 surface soil samples. In addition, 2 surface soil samples were collected between coal gangue hill and pithead power plant, a total of 21 surface soil samples (B1 B21); 5 vertical stratified soil samples $(\mathrm{P} 1 \sim \mathrm{P} 5)$, the vertical stratified sampling depth was $60 \mathrm{~cm}$, divided into 

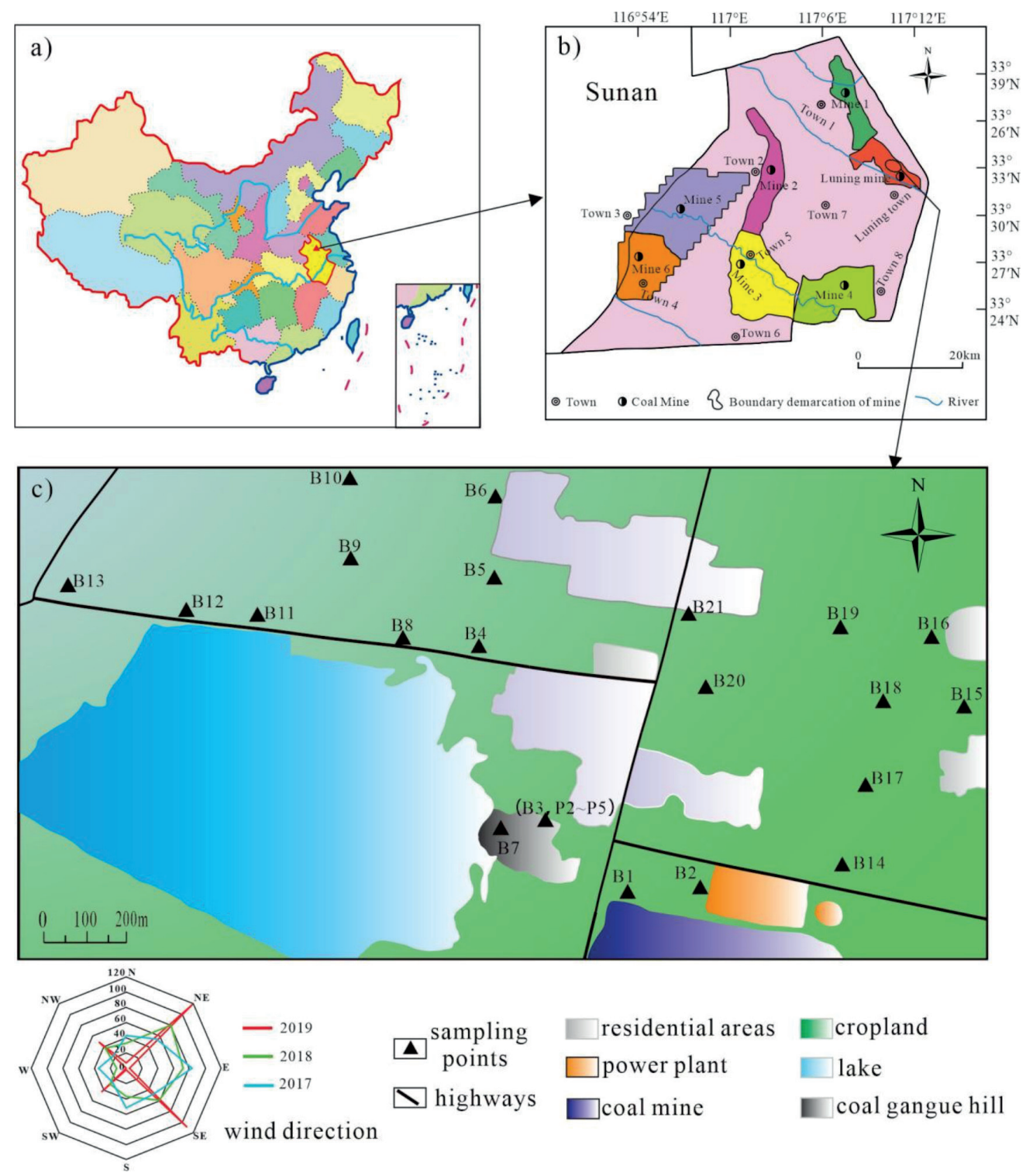

Fig. 1. Geographical location and distribution of sampling points of the study area.

six layers, which are $0 \sim 10 \mathrm{~cm}, 10 \sim 20 \mathrm{~cm}, 20 \sim 30 \mathrm{~cm}$, $30 \sim 40 \mathrm{~cm}, 40 \sim 50 \mathrm{~cm}$ and $50 \sim 60 \mathrm{~cm}$ respectively. The sampling point distribution was shown in Fig. 1c).

Soil samples were taken within the area of $20 \mathrm{~cm} \times 20 \mathrm{~cm}$ square, and the collection depth was $0 \sim 10 \mathrm{~cm}$. The samples were put into a clean sealed bag, labeled well, and the sampling point was positioned by GPS. Meanwhile, the surrounding environment of the sampling point was recorded. After the samples were transported back to the laboratory, they were dried, ground, screened through 200 mesh, put into a sealed bag and labeled for testing.

\section{Sample Test}

The contents of $\mathrm{Cr}, \mathrm{Ni}, \mathrm{Cu}, \mathrm{Zn}, \mathrm{As}, \mathrm{Cd}$ and $\mathrm{Pb}$ in the samples were determined by $\mathrm{X}$-ray fluorescence (XRF) [17-19]. First, tablet with a special fluorescent boric acid abrasive and manual powder tablet press.
A proper amount of soil samples after sieving was taken and put in the middle of the funnel. Then boric acid powder was put on the outside of the funnel, then quickly pulled out the funnel, then put the gasket and the upper pressure head in turn. The assembled mold was put into the tablet press, pressurized to about $10 \mathrm{Mpa}$ and held the pressure for one minute. To invert the mould and remove the bottom of the mould, the mould was put into the tablet press again, and pushed out the pressed sample with the screw. After the tablet was made, the contents of heavy metals were measured by XRF, the standard used is GBW07430 (GSS-16).

\section{Pollution Assessment Methods}

\section{Single Factor Index Method}

Single factor index method reflects single pollution index in soil, which is one of the commonly used 
methods at present [20-21]. Its calculation formula is as follows:

$$
P_{i}=\frac{C_{i}}{S_{i}}
$$

In formula (1), $P_{i}$ represents the pollution index of element $i$ in soil. $C_{i}$ is the actual measured value of element $i\left(\mathrm{mg} \cdot \mathrm{kg}^{-1}\right) ; S_{i}$ is the evaluation standard of element $i\left(\mathrm{mg} \cdot \mathrm{kg}^{-1}\right)$. In this paper, the pollution risk screening values in soil environmental quality--risk control standard for soil pollution in agricultural land (GB15618-2018) [22] and European standard guide maximum allowable limits [23] were taken as the evaluation standard. The single factor pollution index $P_{i}$ were listed in Table 1.

\section{Nemero Comprehensive Pollution Index Method}

The nemero comprehensive pollution index method utilizes the average and maximum values of the single factor pollution index, which can highlight the impact of the maximum pollutant on the soil environment. It is an evaluation method that comprehensively reflects the soil pollution status polluted by various heavy metals [24-25], and its calculation formula is as follows:

$$
P_{n}=\left[\frac{\left(P_{\text {ave }}\right)^{2}+\left(P_{\max }\right)^{2}}{2}\right]^{1 / 2}
$$

In formula (2), $P_{n}$ represents the comprehensive pollution index of heavy metal elements in soil; $P_{\text {ave }}$ represents the average of all single factor pollution indexes; $P_{\max }$ represents the maximum value of all single factor pollution indexes. The classification criteria of nemero composite pollution index $\left(P_{n}\right)$ were listed in Table 1.

\section{Hakanson Potential Ecological Risk Evaluation Method}

Hakanson [26] established a set of methods to evaluate the potential ecological hazards of heavy metals according to the compound effects of heavy metal pollution in soil and the ecotoxicity of different heavy metal elements [27], the calculation formulas are as follows:

$$
\begin{gathered}
E_{r}^{i}=T_{r}^{i} \times C_{o}^{i} / C_{n}^{i} \\
R I=\sum_{i=1}^{n} E_{r}^{i}
\end{gathered}
$$

In formula (3), $E_{r}^{i}$ represents the potential ecological hazard index of a single heavy metal; $C_{0}{ }^{i}$ represents the actual measured value of element $i\left(\mathrm{mg} \cdot \mathrm{kg}^{-1}\right) ; C_{n}{ }^{i}$ represents the reference value of element $i\left(\mathrm{mg} \cdot \mathrm{kg}^{-1}\right)$, in this paper, the surface soil background values of Anhui Province was taken as the reference values. $T_{r}^{i}$ represents the toxicity response coefficient of element $i$, reflecting the response relationship between heavy metals in aqueous phase, sedimentary phase and biological phase [28]. The toxicity response coefficients of $\mathrm{Cr}, \mathrm{Zn}, \mathrm{Ni}, \mathrm{Pb}, \mathrm{Cu}, \mathrm{As}$ and $\mathrm{Cd}$ are 2, 1, 5, 5, 5, 10 and 30 respectively [29]. In formula (4), RI represents the potential ecological hazard index of multiple heavy metals. The classification criteria of the potential ecological hazard index of heavy metals were listed in Table 2.

\section{Results and Discussion}

\section{Characteristics of Heavy Metal Contents in Surface Soil}

According to the test results of heavy metal contents in the surface soil of the study area, it was compared the test results with the background values of heavy metal contents in the surface soil of Anhui Province, the soil pollution risk screening values of Chinese soil environmental quality [22] and the standard guide maximum allowable limits of Europe [23]. The statistical characteristics were shown in Table 3.

Visibly, in addition to the average content of $\mathrm{Ni}$ was lower than the background value, the average content of $\mathrm{Zn}$ closed basically to the background value, the average contents of 5 kinds of heavy metal $\mathrm{Cr}, \mathrm{Pb}, \mathrm{Cu}$, As and $\mathrm{Cd}$ were 77.32, 36.89, 24.23, 17.97, $0.22 \mathrm{mg} \cdot \mathrm{kg}^{-1}$, which were $1.16,1.39,1.19,2.00$,

Table 1. Classification standards of single factor pollution index and comprehensive pollution index.

\begin{tabular}{|c|c|c|c|c|}
\hline Hierarchy & Single factor pollution index & Composite pollution index & Pollution grade & Pollution level \\
\hline 1 & $P_{i} \leq 0.7$ & $P_{n} \leq 0.7$ & Safety & Clean \\
\hline 2 & $0.7<P_{i} \leq 1.0$ & $0.7<P_{n} \leq 1.0$ & Alert & Still clean \\
\hline 3 & $1.0<P_{i} \leq 2.0$ & $1.0<P_{n} \leq 2.0$ & Slight pollution & Slight pollution \\
\hline 4 & $2.0<P_{i} \leq 3.0$ & $2.0<P_{n} \leq 3.0$ & Moderate pollution & Moderate pollution \\
\hline 5 & $P_{i}>3.0$ & $P_{n}>3.0$ & Serious pollution & Serious pollution \\
\hline
\end{tabular}


Table 2. Classification standard of heavy metal potential ecological hazard index.

\begin{tabular}{|c|c|c|c|}
\hline Rank & $E_{r}{ }^{i}$ & $R I$ & The degree of pollution \\
\hline I & $E_{r}{ }^{i}<40$ & $R I<150$ & Low hazard \\
\hline II & $40 \leq E_{r}{ }^{i<80}$ & $150 \leq R I<300$ & Moderate hazard \\
\hline III & $80 \leq E_{r}{ }^{i}<160$ & $300 \leq R I<600$ & Strong hazard \\
\hline IV & $160 \leq E_{r}{ }^{i<320}$ & $R I \geq 600$ & Very strong hazard \\
\hline V & $E_{r}{ }^{i}>320$ & & Extremely dangerous \\
\hline
\end{tabular}

Table 3. Statistical analysis of heavy metal contents in surface soil.

\begin{tabular}{|c|c|c|c|c|c|c|}
\hline Element & $\begin{array}{c}\text { Mean/ } \\
\left(\mathrm{mg} \cdot \mathrm{kg}^{-1}\right)\end{array}$ & $\begin{array}{l}\text { Standard } \\
\text { deviation/ } \\
\left(\mathrm{mg} \cdot \mathrm{kg}^{-1}\right)\end{array}$ & $\begin{array}{l}\text { Background } \\
\text { values/ } \\
\left(\mathrm{mg} \cdot \mathrm{kg}^{-1}\right)\end{array}$ & $\begin{array}{l}\text { Chinese soil pollution } \\
\text { risk screening } \\
\text { values } /\left(\mathrm{mg} \cdot \mathrm{kg}^{-1}\right)\end{array}$ & $\begin{array}{c}\text { European maximum } \\
\text { allowable } \\
\text { limits } /\left(\mathrm{mg} \cdot \mathrm{kg}^{-1}\right)\end{array}$ & $\begin{array}{l}\text { Coefficient of } \\
\text { variation/(\%) }\end{array}$ \\
\hline $\mathrm{Cr}$ & 77.32 & 6.32 & 66.5 & 200 & 100 & 8 \\
\hline $\mathrm{Zn}$ & 62.77 & 9.74 & 62 & 250 & 300 & 16 \\
\hline $\mathrm{Ni}$ & 21.57 & 8.28 & 29.8 & 100 & 50 & 38 \\
\hline $\mathrm{Pb}$ & 36.89 & 3.40 & 26.6 & 120 & 100 & 9 \\
\hline $\mathrm{Cu}$ & 24.23 & 7.00 & 20.4 & 100 & 100 & 29 \\
\hline As & 17.97 & 3.69 & 9 & 30 & 20 & 21 \\
\hline $\mathrm{Cd}$ & 0.22 & 0.02 & 0.097 & 0.30 & 3 & 11 \\
\hline
\end{tabular}

2.27 times the background soil values of Anhui Province respectively (Fig. 2), this indicated that the 5 heavy metals in the soil in the study area have produced different levels of pollution accumulation, among them, the contents of $\mathrm{Cr}$ and $\mathrm{Cu}$ were relatively low, the content of $\mathrm{Cd}$ was relatively high. Compared the average contents of heavy metals such as $\mathrm{Cr}, \mathrm{Zn}, \mathrm{Ni}$, $\mathrm{Pb}, \mathrm{Cu}, \mathrm{As}$ and $\mathrm{Cd}$ in the surface soil of the study area with the soil pollution risk screening values of Chinese soil environmental quality [22] and the standard guide maximum allowable limits of Europe [23], the average

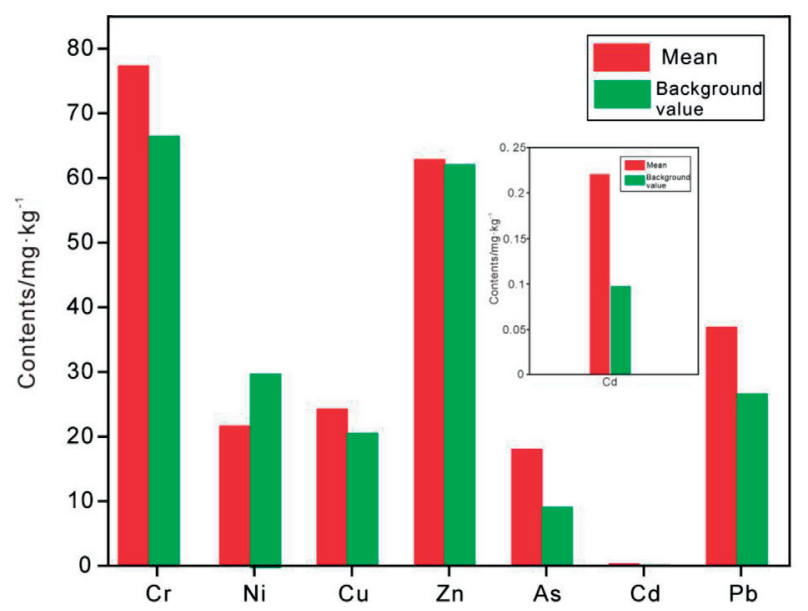

Fig. 2. Histogram of heavy metal contents in the study area and surface soil background values in Anhui Province. contents of 7 heavy metals were less than these two safety limits. It indicated that the pollutants in the soil around the area have low risk to the quality and safety of agricultural products, crop growth or soil ecological environment, and can be ignored under normal circumstances.

Coefficient of variation is the ratio of standard deviation to mean, which reflects the degree of dispersion of data. According to Wilding's classification of variation degree, could know that $\mathrm{Cr}, \mathrm{Pb}, \mathrm{Cd}(8 \%$, $9 \%, 11 \%)$ were low variation $(<15 \%), \mathrm{Zn}, \mathrm{Cu}, \mathrm{As}(16 \%$, $29 \%, 21 \%)$ were medium variation $(15 \%<\mathrm{CV}<36 \%)$, and $\mathrm{Ni}(38 \%)$ were high variation $(\mathrm{CV}>36 \%)$. Therefore, $\mathrm{Cu}$ and $\mathrm{Ni}$ had the highest coefficient of variation and the highest degree of dispersion, indicating that these two elements were not evenly distributed and might be affected by human factors.

\section{Evaluation of Heavy Metal Pollution in Surface Soil}

According to formula (1), the calculation result of soil single factor pollution index in the study area was shown in Fig. 3a). Cd had the largest pollution index, 14 sampling points reached the alert limit, and had the largest accumulation degree. Secondly, the pollution index of As was relatively high, up to 0.84 , indicating that As also had a certain degree of accumulation. $\mathrm{Ni}$ had the smallest pollution index, with the lowest being 0.11 . Formula (2) was used to calculate the nemero comprehensive pollution index, as shown in Fig. 3b). 

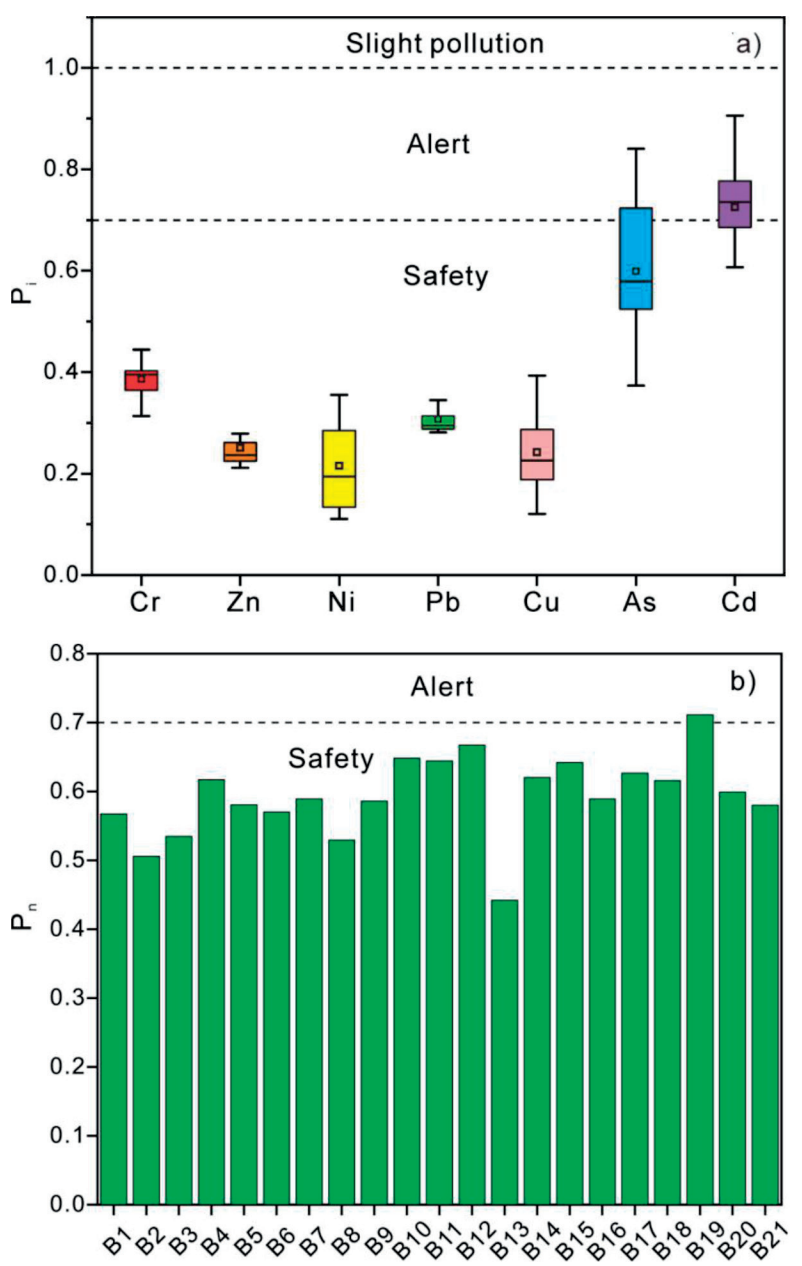

Fig. 3. Box diagram of single factor pollution assessment a) and integrated nemero pollution assessment $b$ ).

$P_{n}$ ranged from 0.43 to 0.70 , and only one sampling site had a higher pollution index, reaching the alert limit.

The potential ecological hazard index for a single heavy metal calculated by formula (3) was shown in Fig. 4a), the ecological hazard index of $\mathrm{Cd}$ is the largest, $95 \%$ of the samples in a moderate hazard, $5 \%$ of the samples in a considerable hazard, between moderate and considerable ecological hazard level, except ecological hazard index of As was close to 40, the rest of the ecological hazard index of heavy metals were far less than 40 , belonged a low ecological hazard, among them, $\mathrm{Zn}$ had the minimum ecological hazard. According to formula (4), the calculation results of the potential ecological hazard index of several heavy metals were shown in Fig. 4b). The $R I$ ranged from 81.81 to 121.41 , all of which were low ecological hazards.

Comparing the two pollution evaluation methods, it was found that $\mathrm{Cd}$ in the soil of the study area had a certain degree of pollution accumulation effect and ecological harm, which was related to its higher content. When evaluated by the single factor pollution index, $29 \%$ of As had a higher pollution index and reached the alert limit. Ni had the lowest pollution index, however,
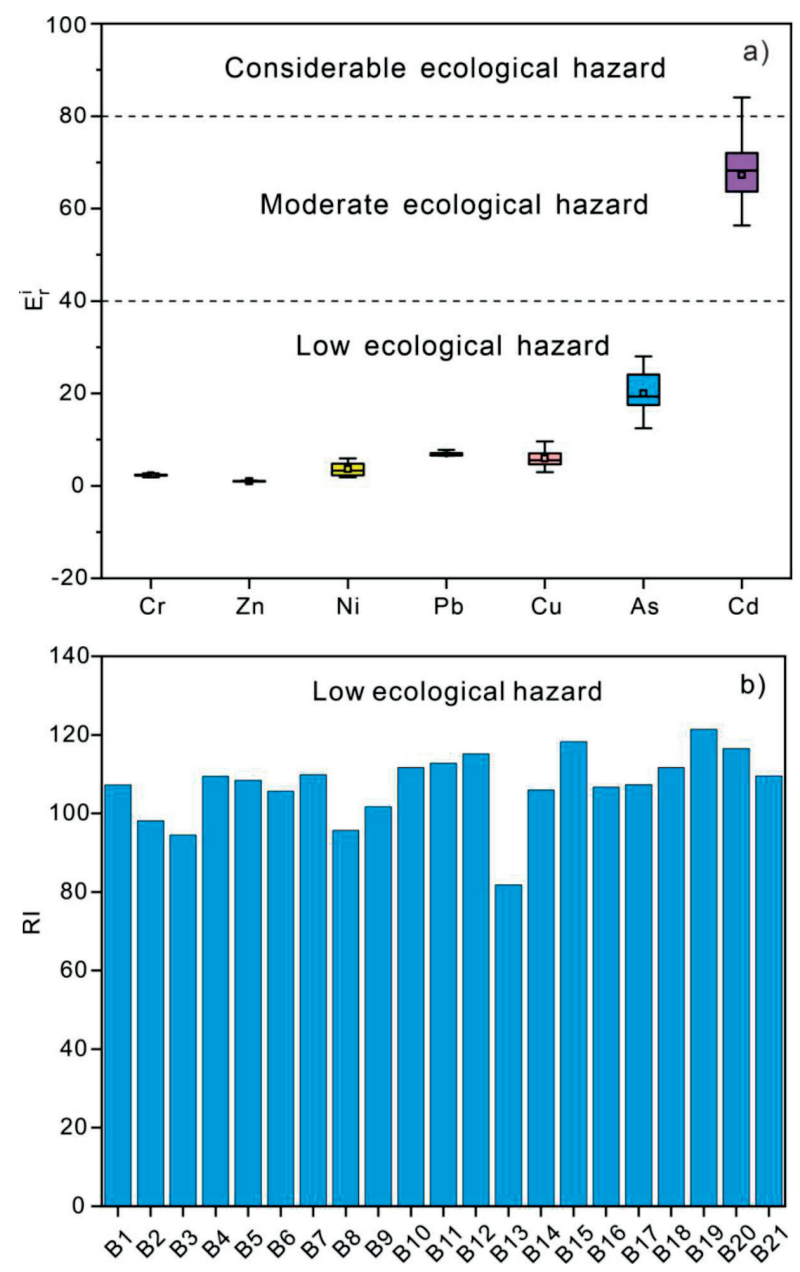

Fig. 4. Bar chart of potential ecological hazard assessment of single heavy metal a) and multiple heavy metal b).

if evaluated by Hakanson's potential ecological risk assessment method, As is in a low ecological hazard, and $\mathrm{Zn}$ had the lowest ecological hazard index. The reason for this phenomenon may be that some heavy metals are highly enriched, but their pro granularity makes it adsorbed by other particulate matter into the soil for mineralization and burial, thus reducing their toxicity to organisms [30]. Therefore, only by combining the accumulation of heavy metals in the soil environment with the potential ecological hazard to the ecosystem can the pollution status of heavy metals in the soil be fully reflected [31]. When using the nemero comprehensive pollution index, $95 \%$ of the sampling points were within the safety limit, while when using the potential ecological risk evaluation method of Hakanson, all the sampling points were in low ecological hazard, and the results of the two methods were basically consistent.

\section{Vertical Migration Characteristics of Heavy Metals in Soil}

In order to study the vertical migration characteristics of heavy metals in the soil of the mining area, the soil 
in the study area was sampled vertically stratified, and the analysis results were shown in Fig. 5 and 6 . The content ranges of $\mathrm{Cr}, \mathrm{Zn}, \mathrm{Ni}, \mathrm{Pb}, \mathrm{Cu}, \mathrm{As}$ and $\mathrm{Cd}$ were 61.15 79.71, 58.89 69.31, 11.21 39.84, 36.80 37.75, 19.74 32.73, $\quad 10.35 \sim 15.69$, and $\quad 0.17 \sim 0.23 \mathrm{mg} \cdot \mathrm{kg}^{-1}$, the 7 heavy metal elements contents of the 6 vertical layered samples have reached the the soil pollution risk screening values of Chinese soil environmental quality [22], and European standard guide maximum allowable limits [23].

The Fig. 5 and Fig. 6 showed that, except the contents of $\mathrm{Cd}$ and $\mathrm{Pb}$ remained unchanged within the range of $0 \sim 60 \mathrm{~cm}$ depth basically, the contents of the other 5 heavy metal elements $(\mathrm{Cr}, \mathrm{Ni}, \mathrm{Cu}, \mathrm{Zn}$, As) all fluctuate significantly within the range of $0 \sim 30 \mathrm{~cm}$, indicating that these 5 heavy metal elements have relatively obvious migration within the range of $0 \sim 30 \mathrm{~cm}$. From 0 to $30 \mathrm{~cm}$, the variation trend of As content was first decreased and then increased, and the highest content was found at $20 \sim 30 \mathrm{~cm}$, which may be related to natural precipitation and diversion irrigation; The change trends of $\mathrm{Ni}$ and $\mathrm{Cu}$ contents were reduced after rising first, both rose sharply at $10 \sim 20 \mathrm{~cm}$, and decreased sharply at $20 \sim 30 \mathrm{~cm}$, the maximum content appeared at 10 20 cm, the lowest value appeared at $20 \sim 30 \mathrm{~cm}$, it may be because $10 \sim 20 \mathrm{~cm}$ was the depth of fertilization and the depth of plant root development, the application of organic fertilizer and the development of plant roots could cause heavy metals not easy to migrate downward [32], thereby

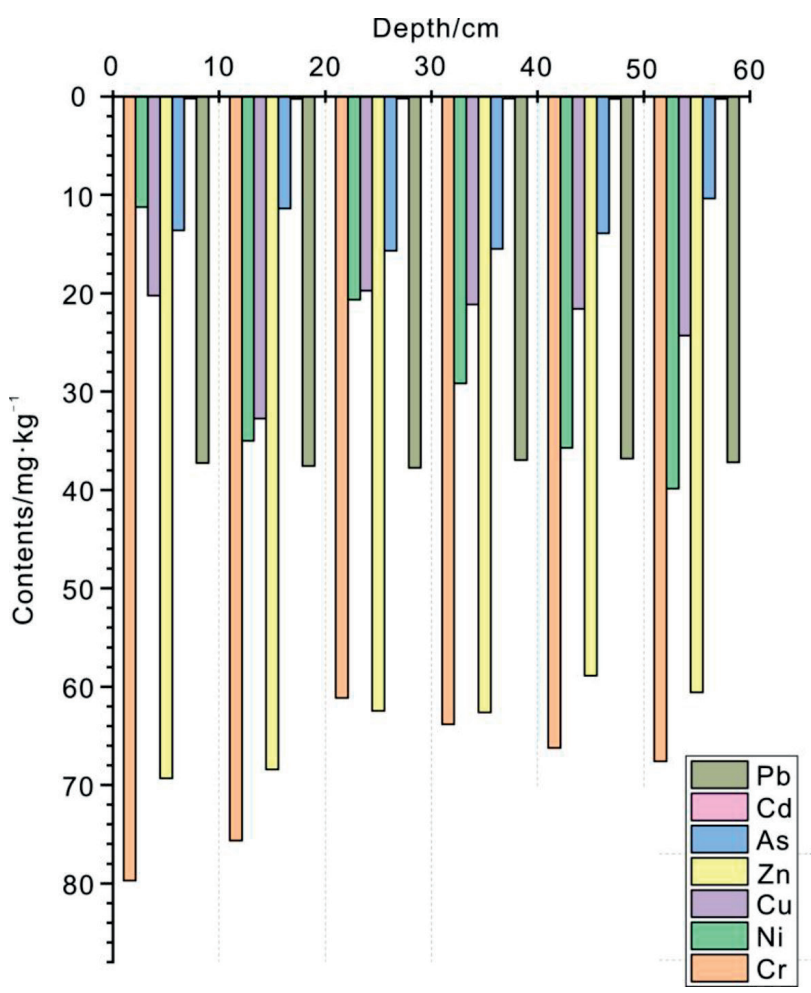

Fig. 5. Histogram of distribution characteristics of soil heavy metal profile. appear the phenomenon that the contents of heavy metals rose sharply at $10 \sim 20 \mathrm{~cm}$. The content of $\mathrm{Cr}$ and $\mathrm{Zn}$ decreased gradually within the range of $0 \sim 30$ $\mathrm{cm}$, and the highest content was found in the surface soil, indicating that these two elements were greatly disturbed by human factors. From $30 \mathrm{~cm}$ to $60 \mathrm{~cm}$, the contents of $\mathrm{Ni}, \mathrm{Cu}$ and $\mathrm{Cr}$ all showed a trend of gradual increase, which may be related to illivuation [33], the eluviation caused by natural rainfall or irrigation causes heavy metal elements to migrate downward and deposition occurred within the range of $30 \sim 60 \mathrm{~cm}$, leading to the increase of heavy metal elements; The contents of As and $\mathrm{Zn}$ showed a gradually decreasing trend, indicating that these two elements also had the abilities of vertical migration, but the migration amount was small.

From the above analysis, it can be seen that the vertical migration characteristics of different heavy metal elements in the soil in the study area were different, the difficulty level was from easy to difficult was $\mathrm{Cr}>\mathrm{Ni} \& \mathrm{Cu}>\mathrm{As}>\mathrm{Zn}>\mathrm{Cd} \& \mathrm{~Pb}$ (the two elements connected by $\&$ represented similar migration ability). The reasons for this difference were related to the contents of organic matter and lime in the soil, the types and quantities of clay minerals, the adsorption abilities of heavy metals to these negative charged surfaces, the adsorption capabilities of plant roots to heavy metals, and the evaporation of water in the soil [34-35].

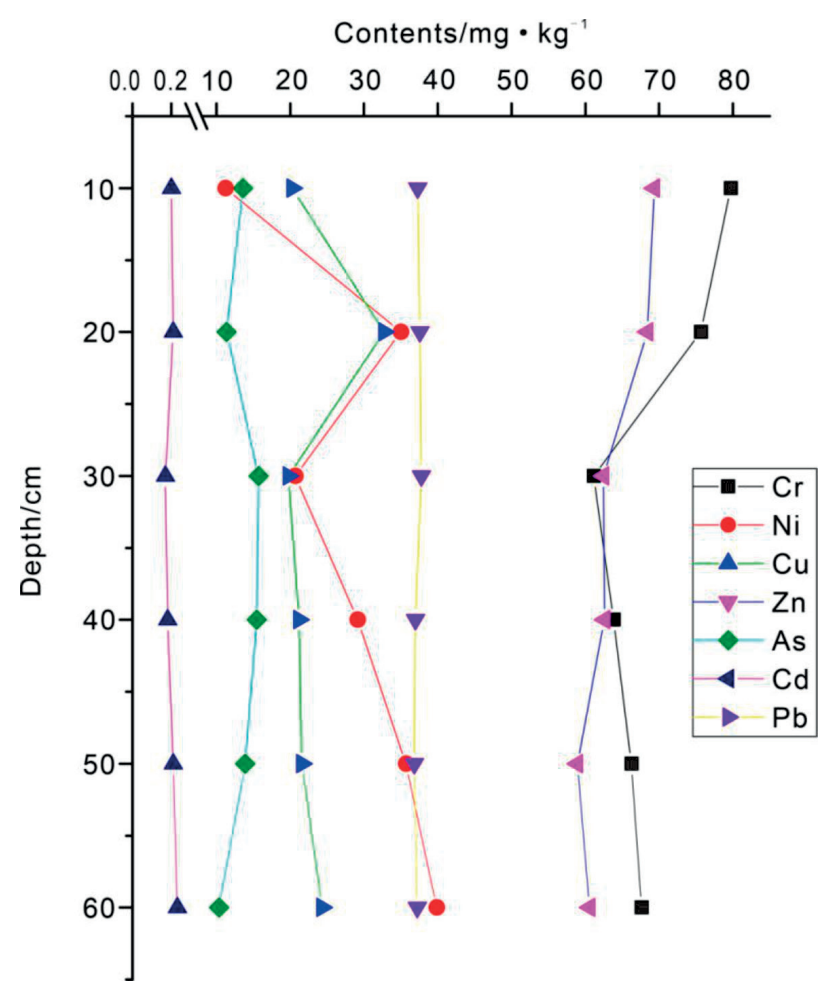

Fig. 6. Scatter diagram of distribution characteristics of soil heavy metal profile. 
Table 4. Correlation analysis results of heavy metal contents.

\begin{tabular}{|c|c|c|c|c|c|c|c|}
\hline Element & $\mathrm{Cr}$ & $\mathrm{Ni}$ & $\mathrm{Cu}$ & $\mathrm{Zn}$ & $\mathrm{As}$ & $\mathrm{Cd}$ & $\mathrm{Pb}$ \\
\hline $\mathrm{Cr}$ & 1.000 & & & & & & \\
\hline $\mathrm{Ni}$ & 0.032 & 1.000 & & & & & \\
\hline $\mathrm{Cu}$ & 0.017 & 0.099 & 1.000 & & & & \\
\hline $\mathrm{Zn}$ & 0.186 & -0.104 & $\mathbf{0 . 4 6 9}$ & 1.000 & & & \\
\hline $\mathrm{As}$ & -0.086 & -0.169 & 0.072 & -0.193 & 1.000 & & \\
\hline $\mathrm{Cd}$ & -0.112 & $\mathbf{0 . 5 6 3 *}$ & -0.007 & -0.168 & -0.030 & 1.000 & \\
\hline $\mathrm{Pb}$ & -0.142 & -0.145 & $\mathbf{0 . 5 1 8}$ & $\mathbf{0 . 3 7 5}$ & -0.294 & $\mathbf{- 0 . 3 9 7}$ & 1.000 \\
\hline
\end{tabular}

** correlation was significant at the level of 0.01 (bilateral) * correlation was significant at the level of 0.05 (bilateral)

\section{Correlation Analysis}

Studies had shown that the correlations between heavy metal elements can reflect whether each element has the same source [36]. It is generally believed that when the correlation coefficient of elements is greater than 0.3 [37], it shows a strong correlation, indicating that elements may have the same source. Pearson correlation analysis results of heavy metal contents were shown in Table 4. The absolute values of Pearson correlation coefficients of $\mathrm{Cd}-\mathrm{Ni}, \mathrm{Zn}-\mathrm{Cu}, \mathrm{Pb}-\mathrm{Cu}$, $\mathrm{Pb}-\mathrm{Zn}$ and $\mathrm{Pb}-\mathrm{Cd}$ were $0.563,0.469,0.518,0.375$ and 0.397 respectively, indicating that $\mathrm{Cd}-\mathrm{Ni}, \mathrm{Cd}-\mathrm{Pb}$, $\mathrm{Zn}-\mathrm{Cu}-\mathrm{Pb}$ were strongly correlated and may had the same source. The correlation coefficients between other elements were all less than 0.3 , with weak correlation. Whether these elements came from the same source could be further determined by cluster analysis and principle component analysis.

\section{Cluster Analysis and Principle Component Analysis}

Cluster analysis and principle component analysis are the main methods to identify the source of heavy metals, and can also reflect whether all elements have the same source [38]. Clustering analysis of the sample point as shown in Fig. 7, when the distance between groups was 15, 21 sampling points could be divided into 4 groups with obvious differences, but $86 \%$ of the sampling points were concentrated in the first two groups, it is indicated that the sampling points were mainly affected by two pollution sources, while the sampling points of the first group were mostly distributed around the coal gangue hill, the sampling points of the second group were mostly distributed around the power plant, indicating that the coal gangue hill and power plant were two different sources of pollution. In order to further determine the sources of seven heavy metal elements in soil, principle component analysis was used.

The principle of principle component analysis is to transform multiple evaluation indicators into a few representative comprehensive indicators by using the idea of dimensionality reduction [39-40]. The loading amount of soil heavy metal principle component factors in the study area was shown in Table 5 and Fig. 8. The information contents of the 7 heavy metals could be reflected by four common factors, with less lost information, and the cumulative contribution rate of the total variance before and after rotation is the same.

According to the loading amount of the factor after rotation, the variance contribution rate of principle component 1 (PC1) was $26.687 \%, \mathrm{Cu}, \mathrm{Zn}$ and $\mathrm{Pb}$ all had large positive loading, while $\mathrm{As}$ and $\mathrm{Cr}$ had negative loading. Therefore, $\mathrm{Cu}, \mathrm{Zn}$ and $\mathrm{Pb}$ may came from the same pollution source, which was consistent with the above correlation analysis result. As could be seen from Table 3, the variation coefficient of $\mathrm{Cu}$ was relatively large, and the contents of a few samples were relatively high. Although $\mathrm{Pb}$ was a low variation, its average content was 1.39 times of the soil background value of Anhui Province, which had caused pollution accumulation. In most cases, the contribution of human sources to trace element input is greater than that of natural sources [41], so $\mathrm{Cu}, \mathrm{Zn}$ and $\mathrm{Pb}$ could be

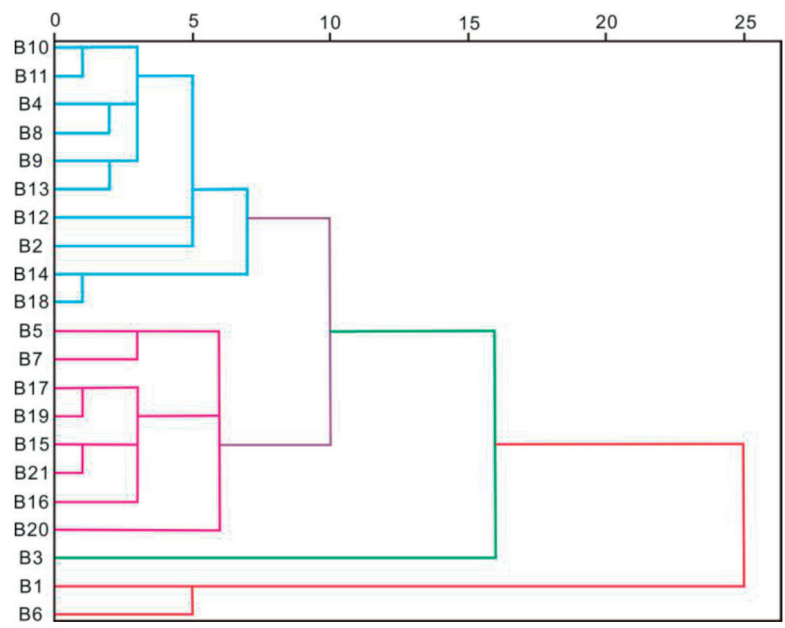

Fig. 7. Clustering analysis results of heavy metal element contents. 
Table 5. Principle component analysis of heavy metals in soil.

\begin{tabular}{|c|c|c|c|c|c|c|c|c|}
\hline \multirow{2}{*}{ Element } & \multicolumn{4}{|c|}{ Before rotation } & \multicolumn{4}{c|}{ After rotation } \\
\cline { 2 - 10 } & PC1 & PC2 & PC3 & PC4 & PC1 & PC2 & PC3 & PC4 \\
\hline $\mathrm{Cr}$ & 0.089 & 0.050 & -0.847 & 0.434 & 0.039 & -0.032 & -0.044 & 0.955 \\
\hline $\mathrm{Ni}$ & -0.371 & 0.805 & -0.001 & 0.001 & 0.046 & 0.871 & -0.158 & 0.029 \\
\hline $\mathrm{Cu}$ & 0.631 & 0.450 & 0.333 & 0.414 & 0.912 & 0.132 & 0.174 & -0.050 \\
\hline $\mathrm{Zn}$ & 0.711 & 0.278 & -0.190 & 0.230 & 0.730 & -0.124 & -0.163 & 0.312 \\
\hline $\mathrm{As}$ & -0.232 & -0.403 & 0.447 & 0.732 & -0.038 & -0.094 & 0.968 & -0.063 \\
\hline $\mathrm{Cd}$ & -0.587 & 0.660 & 0.147 & 0.090 & -0.132 & 0.883 & 0.078 & -0.071 \\
\hline $\mathrm{Pb}$ & 0.827 & 0.128 & 0.229 & -0.290 & 0.693 & -0.332 & -0.390 & -0.309 \\
\hline $\mathrm{Eigenvalue}$ & 2.132 & 1.544 & 1.138 & 1.041 & 1.868 & 1.691 & 1.179 & 1.118 \\
\hline Variance contribution rate/\% & 30.461 & 22.062 & 16.263 & 14.874 & 26.687 & 24.160 & 16.849 & 15.965 \\
\hline $\begin{array}{c}\text { Total variance contribution } \\
\text { rate/\% }\end{array}$ & 30.461 & 52.525 & 68.787 & 83.662 & 26.687 & 50.848 & 67.696 & 83.662 \\
\hline
\end{tabular}

considered to be controlled by human factors. As the sampling site is located in the farmland area near gangue hill and power plant, as well as along the main road of the mining area, there are frequent passing vehicles and serious automobile exhaust emissions. While $\mathrm{Cu}$ and $\mathrm{Pb}$ are the marking elements of automobile exhaust [42], $\mathrm{Zn}$ mainly comes from the wear of tires and brake pads [43]. Therefore, PC1 can be interpreted as automobile exhaust emission and transportation dust.

The contribution rate of principle component 2 (PC2) accounted for $24.160 \%$ of the total contribution rate. In this study area, the accumulation degree and ecological hazard of $\mathrm{Cd}$ were the most serious. The reason was that the long-term stacked coal gangue hill was leached by rainwater, and the heavy metal $\mathrm{Cd}$ migrated into the surrounding soil with the flow of water, forming accumulation. The source of $\mathrm{Ni}$ in

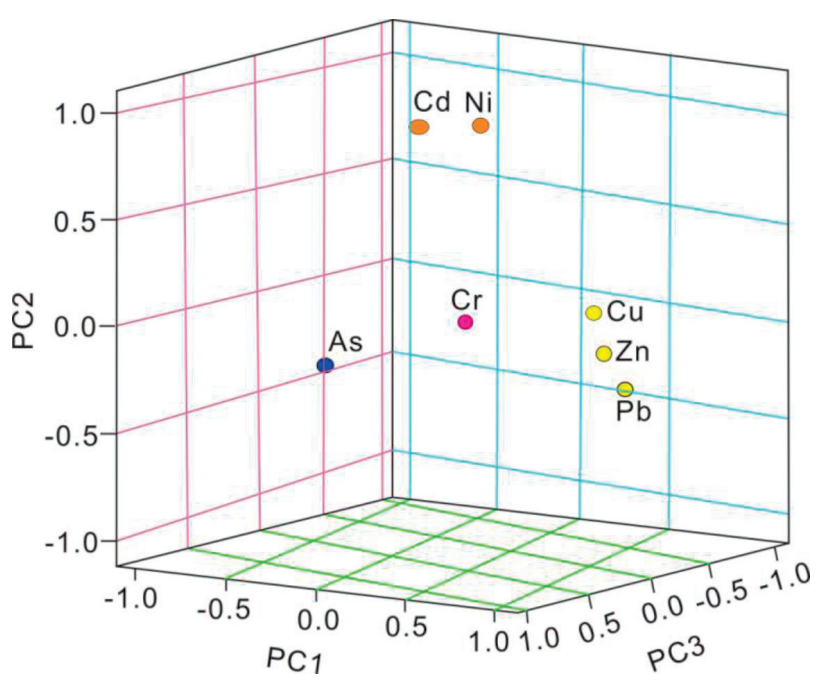

Fig. 8. Three dimensional scatter diagram of soil heavy metal factor loading. soil was mainly the result of geological effects, which is closely related to the formation processes of soil, rock and rock weathering [44]. However, the variation coefficient of $\mathrm{Ni}$ in the study area was relatively large, which indicated that it was also influenced by human factors. Ni is widely used in the production of industrial machinery and precision electronic instruments, metallurgy, electroplating and other fields, and $\mathrm{Ni}$ oxides and hydroxides can also be used in rechargeable batteries [44]. There is an electronics factory $2500 \mathrm{~m}$ south of the study area, due to the prevailing southeast wind in the area in the summer, it will accumulated heavy metals $\mathrm{Ni}$ in the soil of the study area. Therefore, PC2 can be resolved into geological effects (ie natural resources) and coal gangue leaching, followed by industrial pollutant emissions.

Principle component 3 (PC3) explained 16.849\% of the contribution rate of total variance, and the load of As was large, which was consistent with the above correlation analysis results. Because the sampling site is located in the farmland area, a large amount of fertilizer is needed for planting crops, and the harmful heavy metal elements (such as $\mathrm{As}, \mathrm{Cd}, \mathrm{Pb}$, etc.) in the fertilizer may be stored in the soil in the form of fertilizer, resulting in a large accumulation of As [45]. Thus, PC3 represents agricultural activity.

The contribution rate of principle component 4 (PC4) to the total variance was $15.965 \%$, and the heavy metal with large load was $\mathrm{Cr}$, which was consistent with the correlation analysis results. $\mathrm{Cr}$ can enter the surrounding soil through sewage discharge, atmospheric settlement and other means during the operation of coal-fired power plants, causing certain accumulation. Therefore, PC4 can be interpreted as coal combustion.

Generally speaking, there are three main ways of soil pollution, one is natural sources, the other is man-made sources, and the third is the combination of natural and man-made sources. Man-made sources 
mainly include traffic pollution, industrial activities, agricultural activities, fossil fuel combustion, mining activities and so on. Yazhu Wang [46] et al. analyzed the sources of heavy metals in the soil of Jiangsu Province, showing that $\mathrm{Cr}, \mathrm{Cu}, \mathrm{Zn}$, and As were affected by both natural and anthropogenic sources, while $\mathrm{Cd}$ and $\mathrm{Pb}$ were mainly affected by the latter. Gaoqi Jin [47] et al. studied the heavy metals in the cultivated soils in Shaoxing City, Zhejiang Province, and found that the $\mathrm{Pb}$ mainly came from mining activities, $\mathrm{Ni}$ and $\mathrm{Zn}$ were mainly affected by its parent material, $\mathrm{Cu}$ and $\mathrm{Zn}$ were mainly affected by agricultural activities, and $\mathrm{Cd}$ mainly came from chemical fertilizers. Kuangjia Li [48] et al. analyzed the source of heavy metals in the soil around a coal mine in Henan Province and concluded that $\mathrm{Cd}, \mathrm{Pb}, \mathrm{Cu}$ and $\mathrm{Zn}$ came from gangue heap. Jun Liu [49] et al. by studying the soil heavy metals in upland farmland around the coal mine in grassland area, found that $\mathrm{Zn}$ mainly came from transportation, Ni mainly came from agricultural production, and $\mathrm{Cd}, \mathrm{Hg}$ came from natural mother materials and human activities.

According to previous studies, $\mathrm{Cu}, \mathrm{Zn}$ and $\mathrm{Pb}$ were mainly derived from transportation, $\mathrm{Cd}$ and $\mathrm{Cr}$ pollution was mainly caused by agricultural activities, Ni and As were mainly related to parent materials. In this study, the sources of $\mathrm{Cu}, \mathrm{Zn}$ and $\mathrm{Pb}$ were basically consistent with previous studies, while the sources of $\mathrm{Cd}, \mathrm{Cr}, \mathrm{Ni}$ and As were slightly different from previous studies. The main reason is that Luning coal mine has a long mining history and strong environmental cumulative effect. In addition, there are not only mining activities in this research area, but also power plants and electronic enterprises, etc. Industrial and mining activities and the surrounding environment are complex, so the judgment of soil pollution sources has multiple solutions.

\section{Conclusions}

The conclusions drawn from this research suggested that except for $\mathrm{Ni}$ and $\mathrm{Zn}$, the average contents of the other 5 heavy metals $(\mathrm{Cr}, \mathrm{Pb}, \mathrm{Cu}$, As and $\mathrm{Cd})$ in the soil of the study area all exceeded the background values of surface soil in Anhui Province. However, the average contents of the 7 heavy metals were all less than the soil pollution risk screening values of Chinese soil environmental quality and the standard guide maximum allowable limits of Europe, indicating a low risk of soil ecological environment. The single factor pollution index results showed that the pollution index of $\mathrm{Cd}$ was the largest, followed by As, and 14 sampling points of $\mathrm{Cd}$ reached the alert limit. Nemero composite pollution index values ranged from 0.43 to 0.70 , and only 1 sampling point reached the alert limit. According to the potential ecological hazard index of a single heavy metal, Cd had the largest ecological hazard index, with $95 \%$ of the samples in moderate hazard and 5\% in strong hazard. The potential ecological hazard index values of several heavy metals were $81.81 \sim 121.41$, all of which were low ecological hazard. The characteristics of the heavy metal profile in the soil indicated that the heavy metal contents in the soil in this study area did not gradually decrease with increasing depth. The contents of 5 heavy metals $(\mathrm{Cr}, \mathrm{Ni}, \mathrm{Cu}, \mathrm{Zn}, \mathrm{As})$ in the range of $0 \sim 30 \mathrm{~cm}$ had obvious fluctuations, indicating that these 5 heavy metal elements had obvious migration in the range of $0 \sim 30 \mathrm{~cm}$. The difficulty of vertical migration of soil heavy metals in the study area was ranked from easy to difficult: $\mathrm{Cr}>\mathrm{Ni} \& \mathrm{Cu}>\mathrm{As}>\mathrm{Zn}>\mathrm{Cd} \& \mathrm{~Pb}$. The reasons for this difference were related to the contents of organic matter and lime in the soil, the types and quantities of clay minerals, the adsorption abilities of heavy metals to these negative charged surfaces, the adsorption capabilities of plant roots to heavy metals, and the evaporation of water in the soil. Pearson correlation analysis showed that there were strong correlations between heavy metals $\mathrm{Cd}$ and $\mathrm{Ni}$, $\mathrm{Cd}$ and $\mathrm{Pb}, \mathrm{Zn}, \mathrm{Cu}$ and $\mathrm{Pb}$ in the study area, reflecting the two main pollution source characteristics of coal gangue hills and power plants. The principle component analysis results showed that $\mathrm{Cu}, \mathrm{Zn}$ and $\mathrm{Pb}$ were related to automobile exhaust emissions and transportation dust, $\mathrm{Cd}$ and $\mathrm{Ni}$ were mainly caused by natural geological processes, leaching of coal gangue hill and the discharge of industrial pollutants, As was mainly caused by agricultural activities, and $\mathrm{Cr}$ was closely related to coal combustion.

\section{Acknowledgements}

This article is funded by National Training Program of Innovation and Entrepreneurship for Undergraduates(201910379052), National Natural Science Foundation of China (41773100,41373095), Research Project of Huaibei Mining Group Co. (2019), and Research Project of Wanbei Coal-electricity Group Co. Ltd (2019).

\section{Conflict of Interest}

The authors declare no conflict of interest.

\section{References}

1. QIU H.L., GUI H.R., CUI L., PAN Z.G., LU B. Hydrogeochemical characteristics and water quality assessment of shallow groundwater: a case study from Linhuan coal-mining district in northern Anhui Province, China. Water Sci Tech-W Sup, 19 (5), 1572, 2019.

2. LIN M.L., PENG W.H., GUI H.R. Heavy metals in deep groundwater within coal mining area northern Anhui Province, China: concentration, relationship, and source apportionment. Arab J Geosci, 9 (4), 319, 2016.

3. LIU H.B., LIU Z.L. Recycling utilization patterns of coal mining waste in China. Resour Conserv Recy, 54 (12), 1331, 2010. 
4. XIA Y.T., GUI H.R., LI J., GUAN L.S. Temporal variability of hydrochemical characteristics and water quality assessment of collapse pond in Zhuxianzhuang coal mining area, China. Fresen Environ Bull, 28 (1), 402, 2019.

5. GUAN L.S., GUI H.R., KANG Z.Y., ZHAO H.H., LI J. Hydrochemical characteristics and water quality assessment in goaf water of Kouquangou mining area in Datong, Shanxi. Fresen Environ Bull, 27 (12A), 9315, 2018.

6. HUANG D.W., GUI H.R. Distribution features and internal relations of heavy metals in soil-maize system of mining area, Anhui Province, Eastern China. Hum Ecol Risk Assess, 25 (4), 863, 2019.

7. XIONG S., GUI H.R., LIN M.L., PENG W.H. Contents and pollution characteristics of heavy metals in soil from coal mining area: a case study in Linhuan mining district, northern Anhui Province. Fresen Environ Bull, 26 (3), 1989, 2017.

8. LIU X.H., SUN L.H., CHEN S. Heavy metal pollution of soil around the gangue hill: a case study from Zhuxiangzhuang coal mine, northern Anhui Province, China. Adv Mater Res, 356-360, 114, 2012.

9. MEI J., HE H., HONG F.F., LENG Y.W., ZHAO Y.D., ZHENG L., MA C.Y., TAO X.X. Microbial community structures and sulfur speciation characteristics in soil sample around the Xiang-tan Liejiaqiao coal gangue dump, Hunan Province in South of China. Energ Source Part A, 1-2, 2019.

10. LU X.W., XUE X.Y., ZHOU X. Enrichment condition and security risk assessment of heavy metals in soil-crops system around the gangue dumps. IOP Conference Series: Earth and Environmental Science, 170 (5), 052024, 2018.

11. PEKEY H., KARAKAŞ D., BAKOGLU M. Source apportionment of trace metals in surface waters of a polluted stream using multivariate statistical analyses. Mar Pollut Bull, 49 (9-10), 809, 2004.

12. YUAN X.T., ZHANG C.L., SUN Q., WU Y.C. Characteristics of heavy metal content in farmland soils in coal mining areas of Suzhou City. Environmental Chemistry, 30 (8), 1451, 2011.

13. YUAN J.M., YANG D.M., GUO C.Y., XIA H., SUN J. Analysis on evaluation of soil heavy metal pollution in coal mining areas of Chongqing City. Environmental impact assessment, 41 (2), 58, 2019.

14. SU H.M., WANG Z.G., HUANG Y. Heavy metal pollution and ecological risk assessment of farmland soil in Suzhou City coal mining area. Journal of Shandong Normal University (Natural Science Edition), 32 (2), 99, 2017.

15. GUO X.D., SUN Q.F., ZHAO Y.S., CAI H. Identification and characterisation of heavy metals in farmland soil of Hunchun basin. Environ Earth Sci, 78 (10), 310, 2019.

16. ABLIZ A., SHI Q.D., KEYIMU M., SAWUT R. Spatial distribution, source, and risk assessment of soil toxic metals in the coal-mining region of northwestern China. Arab J Geosci, 11 (24), 793, 2018.

17. KODOM K., PREKO K., BOAMAH D. X-ray fluorescence (XRF) analysis of soil heavy metal pollution from an industrial area in Kumasi, Ghana. Soil Sediment Contam, 21(8), 1006, 2012.

18. ENE A., BOŞNEAGĂ A., GEORGESCU L. Determination of heavy metals in soils using XRF technique. Rom J Phys, 55(7-8), 815, 2010.

19. DENG S.P., FAN P.F., TANG Y.S., TAN L.J., WANG Z., HUANG L.N., XU H.L. X-ray fluorescence spectrometry
(XRF) was used to determine 9 heavy metal elements in soil contaminated samples. Chinese inorganic analytical chemistry, 9 (04), 12, 2019.

20. ZENG S.Y., MA J., YANG Y.J., ZHANG S.L., LIU G.J., CHEN F. Spatial assessment of farmland soil pollution and its potential human health risks in China. Sci Total Environ, 687, 642, 2019.

21. LIANG Z.B., GAO L., ZHAO X.F., CHEN J.Y., XIE Z.L., LI S.H., LI R., YANG Z.G. Assessment of metal pollution, its potential health risks, and origin in different land use types in Zhuhai city, China. Arch Environ Con Tox, 76 (2), 295, 2019.

22. Ministry of Ecology and Environment, PRC, \& State Administration for Market Regulation,Soil environmental quality Risk control standard for soil contamination of agricultural land (GB15618-2018). 2018.

23. CHIROMA T.M., EBEWELE R.O., HYMORE F.K. Comparative assessement of heavy metal levels in soil, vegetables and urban grey waste water used for irrigation in Yola and Kano. International Refereed Journal of Engineering and Science, 3 (2), 1, 2014.

24. BENHADDYA M.L., HALIS Y., LAHCINI A. Concentration, distribution, and potential aquatic risk assessment of metals in water from chott merouane (ramsar site), Algeria. Arch Environ Con Tox, 77, 127, 2019.

25. ZHANG S.W., WANG L.J., ZHANG W.J., WANG L., SHI X.M., LU X.W., LI X.P. Pollution assessment and source apportionment of trace metals in urban topsoil of Xi'an city in northwest China. Arch Environ Con Tox, 77, 575, 2019.

26. HAKANSON L. An ecological risk index for aquatic pollution control. A sedimentological approach. Water Res, 14 (8), 975, 1980.

27. KOWALSKA J.B., MAZUREK R., GASIOREK M., ZALESKI T. Pollution indices as useful tools for the comprehensive evaluation of the degree of soil contamination-A review. Environ Geochem Hlth, 40 (6), 2395, 2018.

28. SUN L.W. Research and source analysis of heavy metal pollution in topsoil around power plants. (MSc thesis). Beijing: University of North China Electric Power. 2017.

29. DAI B., LV J.S., ZHAN J.C., ZHANG Z.L., LIU Y., ZHOU R.J. Source, spatial distribution and potential ecological risk assessment of heavy metals in typical industrial cities of Shandong Province. Environmental science, 36 (2), 507, 2015.

30. CHENG F., CHENG J.P., SANG H.C., XI S., PI S.S. Evaluation and correlation analysis of heavy metals pollution in soil of Dajinshan island. Environmental science, 34 (3), 1062, 2013.

31. DOU L., ZHOU Y.Z., WANG X.R., YANG Z.J., PENG X.Z., LI X.J. Improvement and application of fuzzy mathematical model for soil heavy metal pollution evaluation. Chinese journal of soil science, 38 (1), 101, 2007.

32. LI H.Z. Vertical distribution characteristics of heavy metals in farmland soil under different membrane conditions. (MSc thesis). Shanxi: Taiyuan University of Technology. 2018.

33. WANG P., LIU J., ZHU J., LI Z.J., TIAN M.Y., ZHANG W. Impact of heavy metal migration on cultivated land quality and pollution risk control in phosphogypsum yard in karst mountain area. Bulletin of Soil and Water Conservation, 39 (04), 294, 2019. 
34. BLAHA U., APPEL E., STANJEK H. Determination of anthropogenic boundary depth in industrially polluted soil and semi-quantification of heavey metal loads using magnetic susceptibility. Environ Pollut, 156 (2), 278, 2008.

35. CUI H.B., MA K.Q., FAN Y.C., PENG X.H., MAO J.D., ZHOU D.M., ZHANG Z.B., ZHOU J. Stability and heavy metal distribution of soil aggregates affected by application of apatite, lime, and charcoal. Environ Sci Pollut Res, 23, 10808, 2016.

36. MAERE T., VILLEZ K., MARSILI-LIBELLI S., NAESSENS W., NOPENS I. Membrane bioreactor fouling behaviour assessment through principal component analysis and fuzzy clustering. Water Res, 46 (18), 6132, 2012.

37. LIU B. Research on Evaluation of Public Utilities Supply in China's Mega Cities Based on Principal Component Analysis. (MSc thesis). Beijing: China university of political science and law. 2009.

38. YANG P.G., YANG M., MAO R.Z., SHAO H.B. Multivariate-Statistical Assessment of Heavy Metals for Agricultural Soils in Northern China. The Scientific World Jo, 2014, 1, 2014.

39. JOLLIFFE I.T., CADIMA J. Principal component analysis: A review and recent developments. Philos T R Soc A, 374, $20150202,2016$.

40. KIM D., KIM S.K. Comparing patterns of component loadings: principal component analysis (PCA) versus independent component analysis (ICA) in analyzing multivariate non-normal data. Behav Res Methods, 44 (4), 1239, 2012.

41. LU L.L. Environmental biogeochemical study of trace elements in the supergene environment of Huainan and Huaibei mining area. (PhD thesis). Anhui: University of science and technology of China. 2017.
42. GRIGORATOS T., MARTINI G. Brake wear particle emissions: a review. Environ Sci Pollut, 22 (4), 2491, 2014.

43. HU R., YAN Y., ZHOU X., WANG Y., FANG Y. Monitoring Heavy Metal Contents with Sphagnum Junghuhnianum Moss Bags in Relation to Traffic Volume in Wuxi, China. Int J Env Res Pub He, 15 (2), 374, 2018.

44. WANG B.S., HUANG Y.Z., WANG N., LI J., LONG J. Research progress on nickel-remediation soil remediation technology. Journal of Agricultural Environmental Science, 37 (11), 2392, 2018.

45. JIAO W.T., CHEN W.P., CHANG A.C., PAGE A.L. Environmental risks of trace elements associated with long-term phosphate fertilizers applications: A review. Environ Pollut, 168, 44, 2012.

46. WANG Y.Z., DUAN X.J., WANG L. Spatial distribution and source analysis of heavy metals in soils influenced by industrial enterprise distribution: case study in Jiangsu Province. Sci Total Environ, 710, 134953, 2019.

47. JIN G.Q., FANG W., SHAFI M., WU D.T., LI Y.Q., ZHONG B., MA J.W., LIU D. Source apportionment of heavy metals in farmland soil with application of APCSMLR model: A pilot study for restoration of farmland in Shaoxing City Zhejiang, China. Ecotox Environ Safe, 184, 109495, 2019.

48. LI K.J., GU Y.S., LI M.Z., ZHAO L., DING J.L., LUN Z.J., TIAN W. Spatial analysis, source identification and risk assessment of heavy metals in a coal mining area in Henan, Central China. Int Biodeter Biodegr, 128, 148, 2018.

49. LIU J., ZHANG C.F., SUN D.J., JIN Y.B. Effects of coal mining in the grassland area on soil nutrients and heavy metals in surrounding dryland farmland. Journal of Ecology and Rural Environment, 35 (7), 909, 2019. 